T)

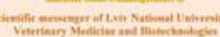

15

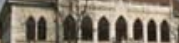

int 10 .

4.9.9.

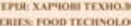

Том $21 \mathrm{Ni} 91$

2019
Науковий вісник Дьвівського національного університету ветеринарної медицини та біотехнодогій імені С.3. Гжицького. Серія: Харчові технології

\author{
Scientific Messenger of Lviv National University
} of Veterinary Medicine and Biotechnologies.

Series: Food Technologies

ISSN 2519-268X print

https://nvlvet.com.ua/index.php/food

doi: 10.32718/nvlvet-f9126

UDC 637.146:635.41]:006.002

\title{
Technological aspects of production of cream cheese with spinach powder
}

\author{
O.I. Melnyk, O.V. Nemirich, A.V. Gavrish, P.M. Gavrilchenko \\ National university of food technologies, Kyiv, Ukraine
}

Article info

Received 11.02.2019

Received in revised form 12.03.2019

Accepted 13.03.2019

National University of Food Technologies, Volodymyrska Str., 68 Kyiv, 01601, Ukraine. Tel.: +38-044-289-54-72 E-mail:melnyk.o93@)gmail.com nemirichav@gmail.com ackvva@gmail.com
Melnyk, O.I., Nemirich, O.V., Gavrish, A.V., \& Gavrilchenko, P.M. (2019). Technological aspects of production of cream cheese with spinach powder. Scientific Messenger of Lviv National University of Veterinary Medicine and Biotechnologies. Series: Food Technologies, 21(91), 157161. doi: 10.32718/nvlvet-f9126

The article proposes a fundamentally new formulation and technology of production of sour milk soft cheese of high biological value, enriched with vitamins, trace elements, and the addition of spinach powder. The generalized functional scheme of cheese production of sour milk soft is provided. The high biological value of cheese obtained by the proposed method is due to the chemical composition of the main components. As a component, it was proposed to use finely divided spinach powder ( 9 .. 20 microns) obtained by drying with mixed heat supply, with a $7 \%$ mass fraction of moisture. This powder has a neutral smell, but with a pronounced taste of spinach, a sweet flavor, a green tint. The healing effect of spinach powder is due to the high content of inulin-based polysaccharides, the presence of pectin substances, $B$ vitamins, and vitamin $C$, the most important trace elements: iron, silicon, potassium, phosphorus, calcium, magnesium, manganese, zinc, copper, and nickel. In this work, improvement of the physical and chemical properties of cream cheese enriched with spinach powder, improvement of the organoleptic properties of cheese, determination of the ability of the spinach powder to absorb the moisture content of the microstructure of the spinach powder of the control sample and in the frozen state. As a result of the research, the use of the recipe components of the new combined milk products on the milk-based basis was substantiated, the formulations were determined and a scale scale was developed for assessing their quality. In addition, the expert method evaluates the quality of combined baking dairy products of high biological value for organoleptic parameters. Taking into account all the abovementioned, it is obvious that the improvement of the recipes of traditional sour-milk products can be accomplished by adding spinach powder and fillers to the main raw material, which makes it possible to create new combined dairy products of high biological value for rational nutrition, as well as to expand the range of existing dairy products in order to meet the growing needs. population. Further research is expected to study the chemical composition of the new dish and the prospects of using the cream as a finishing semi-finished product for flour confectionery products.

Key words: powdered spinach, lactic cheese, quality indicators.

\section{Технологічні аспекти виробництва крем-сиру з порошком зі шпинату}

\author{
О.І. Мельник, О.В. Нєміріч, А.В. Гавриш, П.М. Гаврильченко
}

Національний університет харчових технологій, м.Київ, Украӥна

У статті запропоновано принципово нову рецептуру і технологію виробництва кисломолочного м якого сиру підвищеної біологічної цінності, збагаченого вітамінами, мікроелементами, з додавання порошку шпинату. Подано узагальнену функиіональну схему виробництва сиру кисломолочного м'якого. Висока біологічна иінність сиру, отриманого запропонованим способом, обумовлена хімічним складом основних компонентів. Як компонент запропоновано використовувати дрібнодисперсний порошок зі шиинату (9...20 мкм), отриманий методом сушіння зі змішаним тепло-підведенням, з масовою часткою вологи 7\%. Цей порошок має нейтральний запах, але з вираженим смаком шпинату, солодким присмаком, зеленим відтінком. Цілюща дія порошку зі шпинату зумовлена високим вмістом полісахаридів інулінової природи, наявністю пектинових речовин, вітамінів групи В, вітаміну С, найважливіших мікроелементів: заліза, кремнію, калію, фосфору, кальцію, магнію, марганцю, цинку, міді, нікелю. В даній роботі проведені покрашення фізико-хімічних властивості крем-сиру, збагаченого порошком зі шпинату, покращення органолептичних властивостей сиру, визначення здатності порошку зі шпинату поглинати вологість мікроструктури порошку шпинату контрольного 
зразка і у замороженному стані. В результаті проведеного дослідження було обтрунтовано використання рецептурних компонентів нових комбінованих кисломолочних продуктів на молочно-рослинній основі, визначено рецептуру та розроблено бальну шкалу для оцінки їхньої якості. Крім ичього, експертним методом оцінено якість комбінованих кисломолочних продуктів підвищеної біологічної цінності за органолептичними показниками. 3 вищесказаного випливає, щуо удосконалення рецептур традиційних кисломолочних продуктів можливо здійснювати за рахунок додавання порошку шпинату $і$ наповнювачів до основної сировини, шчо дає змогу створити нові комбіновані кисломолочні продукти підвищеної біологічної цінності для рачіонального харчування, а також розиирити асортимент наявних молочних продуктів задля задоволення все зростаючих потреб населення. Подальшими дослідженнями передбачається вивчення хімічного складу нової страви та перспектив використання крему як оздоблювального напівфабрикату для борочняних кондитерських виробів

Ключові слова: порошок зі шпинату, сир кисломолочний, показники якості.

\section{Вступ}

Велику увагу приділяють кисломолочним продуктам, наголошуючи на біологічній цінності та фізіологічному значенні сирів, оскільки вони містять увесь спектр поживних речовин, в тому числі й незамінних, необхідних людині для життєво важливих процесів (Gutyj et al., 2017; Solomon, 2018). 3 огляду на узагальнення наукових позицій щодо необхідності надання продуктам функціональних властивостей виникає потреба удосконалення рецептури та традиційних методів виробництва сиру (Bilyk et al., 2017).

Дефіцит основних харчових речовин або дисбаланс їх у раціонах людини призводить до незворотних змін внутрішнього середовища організму, порушення клітинного метаболізму. Тому їжа повинна бути різноманітною, мати гарний зовнішній вигляд і задовольняти потреби та звички, що склалися залежно від віку людини, іiі професії, побутових умов, національності та інших особливостей. Енергія, що витрачається людиною в процесі життєдіяльності організму, відновлюється тільки за рахунок їжі. Тому процес харчування має бути керованим і позитивно впливати на фізіологічні, психічні й соціальні функції людини, формувати життєдіяльність, впливати на довголіття та творчий і трудовий потенціал.

Метою роботи було обгрунтування технологічних параметрів виробництва сиру на основі вершків 3 використанням порошку зі шпинату.

\section{Матеріал та методи досліджень}

Аюрведа стверджує, що немає сенсу враховувати дані стосовно вмісту в харчових продуктах білків, жирів, вуглеводів, інших нутрієнтів, головне - оцінити їхню енергетику (Agnivasa, 2011). 3 іншого боку, критичне ставлення Аюрведи до м'яса пояснюється тим, що в ньому надто багато солі, білків і жирів. Окрім цього, до категорії “правильних” продуктів для людей усіх трьох конституційних типів віднесено м'ясо птиці, тому положення та рекомендації Аюрведи, як і вітчизняної нутриціології, не позбавлені деяких суперечностей, що потребує творчого підходу до їх осмислення та використання.

Аюрведичні методи дієтотерапії потребують окремого розгляду, а зараз спробуємо виявити відмінності та спільні підходи східної та західної медицини до формулювання основних принципів харчування як важливої складової системи оздоровлення людини. Як і сучасна вітчизняна медицина, Аюрведа підкреслює пріоритетне значення індивідуально підібраного раці- ону як головного засобу не лише підтримання належного стану здоров'я, а й, за необхідності, тривалого лікування фізичного тіла, що на санскриті називається “анна-майя коша” (“харчова оболонка”). Конкретизуючи заявлену в назві статті тезу, об’єктивності ради слід зазначити, що у харчовому раціоні Аюрведу цікавить передусім вплив енергетики їжі (життєвої енергії) на доші - три основні біологічні елементи, що визначають індивідуальну конституцію людини (Agnivasa, 2011). Особливо великого значення життєвій енергії надає йога - давньоіндійська філософська й оздоровча система (Levshinov, 2004). Так, дихання у цій системі розглядається як прояв життєдайної сили - прани. Згідно з йогою, життєва енергія є в усіх формах життя - від мінералів до людини. Прана міститься в усьому живому. Вона є формою енергії, яку використовує душа у своїй матеріальній та астральній діяльності. Усе тіло контролюється і регулюється силою прани. Це енергія, яка живить матерію. Йога дає загадкове і незрозуміле для європейця тлумачення, що “прана $є$ в повітрі, але це не кисень і не будь-яка 3 його складових частин.” Вона є в їжі, воді і сонячному промінні, але це не вітаміни, не тепло і не сонячний промінь. Їжа, вода, повітря - засоби постачання прани. Ми одержуємо прану через їжу, яку споживаємо, воду, яку п’ємо, та повітря, яким дихаємо. Прана відома також як всесвітня енергія. Вона проявляється як гравітація, електрика, діяльність тіла, нервові струми та сила душі. Все є виявом прани - від думки і до найнижчих проявів фізичної сили. Ці міркування важко спростувати і важко підтвердити. Хоча 3 точки зору класичної європейської науки поняття такої “життєвої енергіï” суперечить законам термодинаміки. У вітчизняній нутриціології характеристика раціону розпочинається 3 хімічного складу продуктів, наявності та співвідношення у них макро- і мікронутрієнтів, ступеня їх безпеки тощо. 3 аюрведичної точки зору стандартної дієти для всіх і кожного бути не може, як не може бути нормована і щоденна потреба індивіда в певних нутрієнтах.

Окремо Аюрведа визначає правила споживання коров'ячого молока, вважаючи його найбільш саттвічною їжею, яка зміцнює тіло та сприяє душевному спокою. Для кращого засвоєння молоко рекомендовано кип'ятити; його не варто споживати 3 тими продуктами, які не поєднуються 3 ним смаками (гострим, кислим, солоним), а вживати лише з солодкою їжею борошняними виробами, кашами, солодкими фруктами або як самостійний продукт. Для людей типу Капха (люди міцної статури, схильні до ожиріння) підходить молоко зниженої жирності, а люди типу Вати 
(худорляві, поривчасті, схильні до тривоги) та Пітти (середньої статури, вольові, вимогливі) мають віддавати перевагу цільному молоку. Варто зазначити, що аюрведична порада пити кип'ячене молоко має своє пояснення також у вітчизняній нутриціології з точки зору виникнення в організмі алергійних реакцій. Так, алергійними властивостями (лише у схильних до алергії людей) відзначаються білки глобуліни, рідше казеїни. При кип'ятінні молока глобуліни переходять у пінку, і алергійні властивості білків різко зменшуються.

Сьогодні дедалі популярнішими в споживачів кисломолочної продукції стають продукти з різноманітними наповнювачами, про що свідчить інтенсивне їх розширення. У виробництві кисломолочних продуктів iз наповнювачами як сировину використовують компоненти тваринного (молоко, закваски, сир) та рослинного (фрукти, ягоди, овочі, спеції) походження. Використання в рецептурі зернобобових та злакових культур також підтримує поширену концепцію підвищення харчової цінності кисломолочних продуктів

Сиркові вироби випускають солодкими (вміст цукру 13-26\%) і солоними (вміст солі 1,5-2,0\%), масова частка жиру в них може бути різною: високожирні вироби (20-26\%), жирні (14,5-15,9\%), напівжирні (7$8 \%$ ), знежирені. Нормалізацію проводять пастеризованими вершками, маслом вершковим або сметаною за рецептурами. На наш погляд, використання рослинної сировини, а саме шпинату, в технології сиркових виробів $є$ дуже перспективним.

Шпинат залишається найбільш поживиною овочевою зеленню. Як і у всіх видах весняної зелені, поживна цінність шпинату зміщена в бік білків (2,9 г/100 г). Вміст жирів і вуглеводів низький. Кількість вітаміну А і бета-каротину в 100 г шпинату забезпечує 90\% добової потреби, а вітаміну К - чотириденну норму, вітаміну С в ньому більше половини денної норми, а крім того, він забезпечує організм практично всіма вітамінами групи В (B1, B2, B5, B6 і В9), вітамінами Е і РР. Окремо варто сказати про фолієву кислоту. Ця речовина вперше була виділена якраз зі шпинату. І хоча в рослині ії 80 мкг, що становить $1 / 5$ денної норми, шпинат може по праву вважатися лідером за іiі вмістом серед зелені, а порівняно з іншими продуктами його випереджають тільки арахіс, печінка і бобові. Великий вміст у рослині Магнію (82 мг в 100 г або 20\% добової потреби), Калію (774 мг або 30\% норми), Мангану (близько 900 мкг або 45\% норми), присутні також Кальцій, Фосфор, Натрій, Цинк, Купрум і Селен. Листя шпинату багате мінеральними солями (Калій, Кальцій), вітамінами (А, C, B1, B2, B3, У6, D, E, K, P, PP), провітаміном А i каротином. Особливість вітамінів С та А в шпинаті вони не руйнуються при варінні. За вмістом білка поступається тільки бобовим культурам (білок у шпинаті за своїми властивостями подібний до білка коров'ячого молока). Такий неперевершений склад звичайного, на перший погляд, листя дає підставу стверджувати, що шпинат має не тільки важливе дієтичне значення, а й може бути зарахований до роду лікарських рослин. Шпинат недарма був названий французами “королем овочів” та “мітлою кишечни- ка". Він містить велику кількість харчових волокон, які не перетравлюються. Насичуючись шлунковим соком, вони набухають i, подібно до щітки, змітаючи різні відкладення на його стінках, виводяться 3 організму (Izbash et al., 2010; Pukivskyi et al., 2015). Проте шпинат протипоказаний людям 3 сечокам'яною хворобою через високий вміст щавлевої кислоти, що сприяє утворенню каменів. Якщо дуже вже хочеться, дію кислоти можна нейтралізувати, запивши шпинат молоком. Не можна вживати шпинат також при гастриті, панкреатиті, виразкових захворюваннях шлунка, підвищеному згортанні крові i, як наслідок, різних видах тромбозу. Листя шпинату, призначене для виробництва сиркової маси, доводили до готовності шляхом смаження на сковорідці без олії. На розігріту сковорідку клали помите листя шпинату, постійно перемішували, піднімаючи нижні листки вгору, а верхні - опускаючи вниз. Визначали готовність шпинату за втратою твердості. Тривалість приготування шпинату таким способом займає близько 2 хв. При виробництві сиркової маси сир кисломолочний закладали у місильну машину, потім вносили компоненти за рецептурою. Таким чином, сиркова маса, виготовлена 3 використанням рослинної сировини, поєднує в собі традиційні споживчі властивості з технологічними можливостями функціонально-технологічних інгредієнтів рослинного походження. Такі технологічні кроки спрямовані на розширення сировинної бази молокопереробного комплексу та розв'язання проблеми зменшення дефіциту основних нутрієнтів у раціонах харчування населення. Вирішити цю проблему неможливо без комплексного наукового підходу.

Як матеріал для збагачення було обрано дрібнодисперсний порошок зі шпинату (9..20 мкм), отриманий методом сушіння зі змішаним тепло-підведенням, 3 масовою часткою вологи 7\%. Цей порошок має нейтральний запах, але 3 вираженим смаком шпинату, солодким присмаком, зеленим відтінком. Цілюща дія порошку зі шпинату зумовлена високим вмістом полісахаридів інулінової природи, наявністю пектинових речовин, вітамінів групи В, вітаміну $\mathrm{C}$, найважливіших мікроелементів: заліза, кремнію, калію, фосфору, кальцію, магнію, марганцю, цинку, міді, нікелю. Завдяки цьому він $є$ дієтичним продуктом та, маючи великий вміст інуліну, здатен знижувати рівень цукру в крові, що актуально для раціонального харчування при цукровому діабеті.

Порошок зі шпинату ГОСТ 34130-2017 Овочі сушені. Методи визначення маси нетто, форми і розміру частинок, величини помелу, дефектів за зовнішнім виглядом, співвідношення компонентів, органолептичних показників і розварюваності.

- модельна система емульсії, яка приготовлена за традиційною технологією;

- модельні системи емульсій, які приготовлено 3 використанням порошку зі шпинату

Сировина, що використовувалась для виготовлення об'єктів досліджень, відповідала вимогам такої діючої нормативної документації:

Крем-сир м'який за ГОСТ 1.0-2015;

Порошок зі шпинату за ГОСТ 34130-201. 


\section{Результати та їх обговорення}

В результаті попередніх досліджень обгрунтовано вибір сировини і технологічних параметрів рецептурної композиції сиру кисломолочного (крем-сиру), що отримано за синергетичної дії молочнокислих бактерій йогурту i сметани при зброджуванні суміші 12 годин за температури $0 \ldots 4^{\circ} \mathrm{C}$. До складу кисломолочного продукту 3 аюрведичними властивостями вносили порошок зі шпинату.

Основною функціонально-технологічною властивістю порошку зі шпинату, що характеризує його поведінку в технологічному процесі, є здатність поглинання вологи з кисломолочного сиру за новою технологією, результати визначення якої показано на рис. 1.

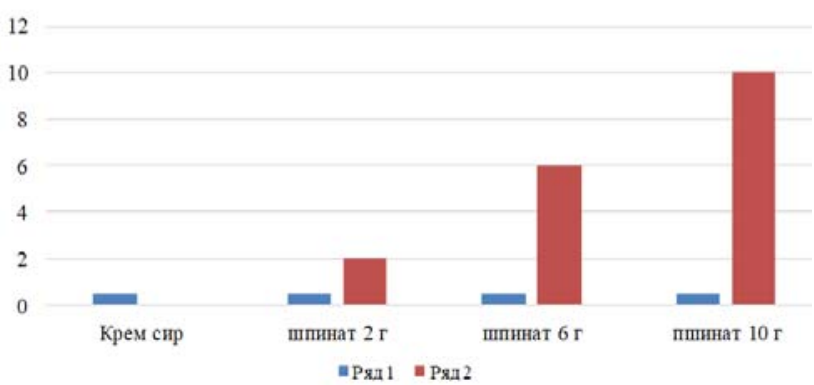

Рис. 1. Водопоглинальна здатність порошку шпинату в крем-сирі

Згідно з проведеними дослідженнями бачимо, що найвищу поглинальну здатність має порошок зі шпинату в третьому зразку, що зумовлено його хімічним складом: вмістом у ньому полімерів, здатних до набухання - білків, крохмалю, пентозанів клітковини. Отримані дані дозволяють прогнозувати високу стійкість до седиментації крем-сиру 3 даною рослинною сировиною, що також підтверджується і фотомоніторингом зразків нової продукції - рис. 2.

Наступним етапом досліджень було визначення впливу порошку зі шпинату на мікроструктуру кремсиру - рис. 3.
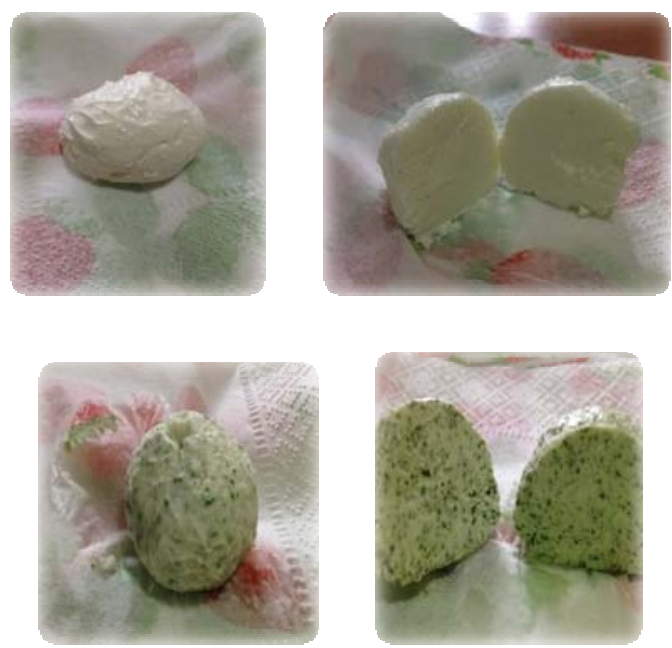

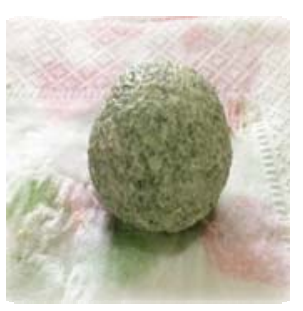

Рис. 2. Зразки нової продукції

а) крем-сир; б) крем-сир в розрізі; в) крем-сир 3 додаванням порошку, шпинату 2 г; г) крем-крем-сир 3 додаванням порошку, шпинату 6 г; д) крем сир кремсир 3 додаванням порошку шпинату 10 г.

Актуальними та доречними є фотографії мікро- чи макроструктур об’єктів дослідження. Приклад:

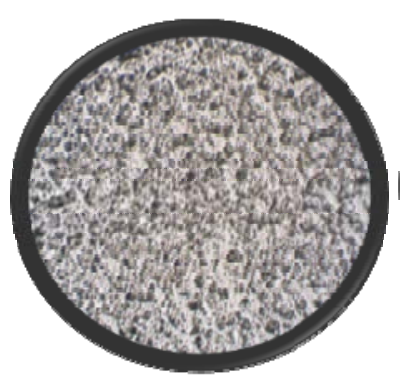

a)

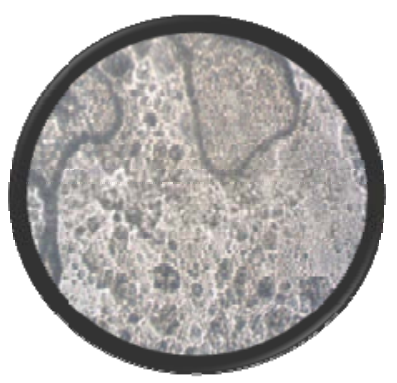

б)
Рис. 3. Мікроструктура крем-сиру з порошком зі шпинату: а - крем-сир (контроль); б - крем-сир з порошком зі шпинату (дослід)

На рис. 3. видно відновлені клітини частинок порошку зі шпинату у крем-сирі (рис. 3а) та спостерігається концентрація складових дисперсної фази, що сконцентровані у вигляді кульок на поверхні окремих часточок рослинного порошку (рис. 3б), видно прояви порошку шпинату в крем-сирі.

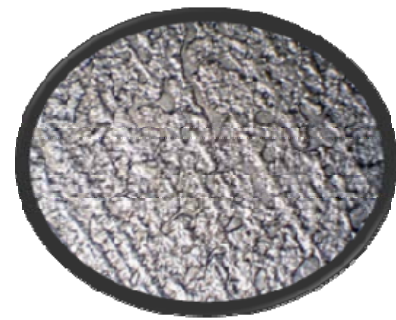

a) $x-40$

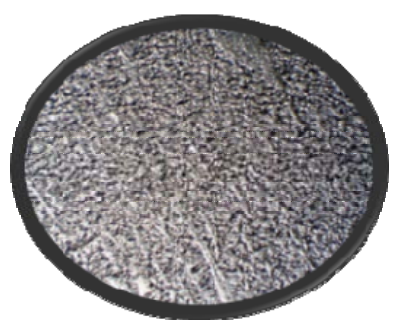

б) $\mathrm{x}-100$
Рис. 4. Мікроструктура порошку шпинату в замороженому стані

Технічним результатом є створення сирного напівфабрикату підвищеної харчової, біологічної цінності 3 поліпшеними органолептичними показниками, збагачений мікроелементами і вітамінами.

При цьому інноваційний продукт вирізняється високими органолептичними властивостями, що показано в табл. 1 . 


\section{Таблищя 1}

Органолептичні показники якості крему на основі вершків, збагаченого порошком зі шпинату

\begin{tabular}{lcl}
\hline \multicolumn{1}{c}{ Показник } & Контрольний зразок сиру кисломолочного & Сир кисломолочний з порошком зі шпинату \\
\hline Зовнішній вигляд & Однорідна маса & Однорідна маса \\
Смак та запах & Нейтральний молочний & Молочний з присмаком шпинату \\
Колір & Білий & Зелений \\
Консистенція & Однорідна, пухка & Однорідна, пухка \\
\hline
\end{tabular}

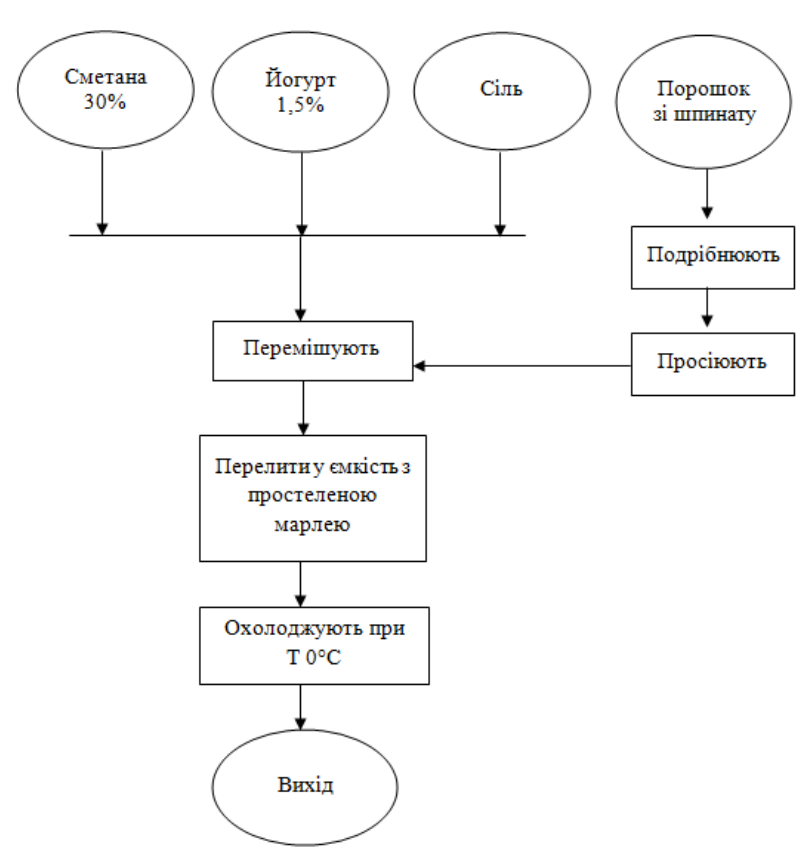

Рис. 4. Узагальнена функціональна схема виробництва сиру кисломолочного з порошком шпинату

Удосконалена рецептура кисломолочного сиру передбачає збагачення його складу вітамінами, вуглеводами, органічними кислотами, мікроелементами тощо. Висока біологічна цінність сиру, отриманого запропонованим способом, обумовлена хімічним складом та впливом на організм людини його основних компонентів

Оскільки якість продукту обумовлена сукупністю властивостей, що відображають органолептичні показники, безпечність та здатність забезпечувати потреби організму в харчових речовинах, можна стверджувати, що сир кисломолочний 3 порошком зі шпинату може стати продуктом високої якості.

\section{Висновки}

В результаті проведеного дослідження було обгрунтовано використання рецептурних компонентів нових комбінованих кисломолочних продуктів на молочно-рослинній основі, визначено рецептуру та розроблено бальну шкалу для оцінки їхньої якості. Крім цього, експертним методом оцінено якість комбінованих кисломолочних продуктів підвищеної біологічної цінності за органолептичними показниками. 3 вищесказаного випливає, що удосконалення рецептур традиційних кисломолочних продуктів можливо здійс- нювати за рахунок додавання порошку шпинату i наповнювачів до основної сировини, що дає змогу створити нові комбіновані кисломолочні продукти підвищеної біологічної цінності для раціонального харчування, а також розширити асортимент наявних молочних продуктів задля задоволення все зростаючих потреб населення

Подальшими дослідженнями передбачається вивчення хімічного складу нової страви та перспектив використання крему як оздоблювального напівфабрикату для борошняних кондитерських виробів.

\section{References}

Agnivasa, A. (2011). Vvedenie v Ajurvedu. per. s angl. Moskva: ProfitStajl (in Russian).

Bilyk, O., Slyvka, N., Gutyj, B., Dronyk, H., \& Sukhorska, O. (2017). Substantiation of the method of protein extraction from sheep and cow whey for producing the cheese "Urda". Eastern-European Journal of Enterprise Technologies, 3, 11(87), 18-22. doi: 10.15587/1729-4061.2017.103548.

Gutyj, B., Hachak, Y., Vavrysevych, J., \& Nagovska, V. (2017). The influence of cryopowder "Garbuz" on the technology of curds of different fat content. EasternEuropean Journal of Enterprise Technologies, 2, 10(86), 20-24. doi: 10.15587/1729-4061.2017.98194.

Izbash, Ye.O., Morhun, V.O., \& Mariniesku, N.H. (2010). Rozrobka parametriv pidhotovky zernovykh dobavok dlia vyrobnytstva molochno-roslynnykh produktiv. Naukovi pratsi ONAKhT. Ser. Tekhnichni nauky. Odesa: ONAKhT, 38(2), 265-268 (in Ukrainian).

Levshinov, A.A. (2004). Sistemy ozdorovlenija Vostoka i Zapada: jenciklopedija. Sankt-Peterburg: PrajmEVROZNAK (in Russian).

Pukivskyi, P., Turchyn, I., Slyvka, N., \& Mykhailytska, O. (2015). Vykorystannia roslynnoi syrovyny v tekhnolohii syrkovykh mas. Naukovyi visnyk Lvivskoho natsionalnoho universytetu veterynarnoi medytsyny ta biotekhnolohii imeni S. Z. Gzhytskoho, 17(4), 105-109. Rezhym dostupu: http://nbuv.gov.ua/UJRN/nvlnu_2015_17_4_22 (in Ukrainian).

Solomon, A. (2018). Bifidostimulating ingredients for dessert fermented products. Scientific Messenger of Lviv National University of Veterinary Medicine and Biotechnologies. 20(90), 53-57. doi: $10.32718 /$ nvlvet9011. 